\title{
Manganese (Mn) Concentrations and the Mn-Fe Relationship in Shallow Groundwater: Implications for Groundwater Monitoring
}

\author{
Kay Hamer, Imke Gudenschwager and Thomas Pichler * \\ Department of Geosciences, University of Bremen, 28357 Bremen, Germany; khamer@uni-bremen.de (K.H.); \\ i.gudenschwager@gmx.de (I.G.) \\ * Correspondence: pichler@uni-bremen.de
}

Received: 23 June 2020; Accepted: 29 July 2020; Published: 5 August 2020

check for updates

\begin{abstract}
Manganese (Mn) concentrations in approximately 32,000 groundwater analyses from more than 4800 monitoring wells in northern Germany were evaluated. This region was considered well suited to study $\mathrm{Mn}$ in shallow groundwater in unconsolidated sediments. Spearman rank correlation was used to correlate between redox-sensitive parameters and the Mann-Kendall test for an evaluation of temporal trends. Manganese concentrations varied over two orders of magnitude and more than $40 \%$ of the wells had concentrations above $0.3 \mathrm{mg} / \mathrm{L}$. Median Mn concentrations in the major hydrogeological units, the Geesten, tidal wetlands, and fluviatile lowlands were $0.12 \mathrm{mg} / \mathrm{L}$, $0.46 \mathrm{mg} / \mathrm{L}$, and $0.27 \mathrm{mg} / \mathrm{L}$, respectively. Separating the data by land use, the median concentrations were $0.20 \mathrm{mg} / \mathrm{L}$ for arable land, $0.15 \mathrm{mg} / \mathrm{L}$ for forests, and 0.24 for grassland. Calculated background concentrations of $\mathrm{Mn}$ varied from $<0.25 \mathrm{mg} / \mathrm{L}$ to $4.79 \mathrm{mg} / \mathrm{L}$. A new parameter, $\Delta \mathrm{Mn}-\mathrm{Fe}$, defined as the concentration difference between $\mathrm{Mn}$ and $\mathrm{Fe}$ in $\mathrm{mg} / \mathrm{L}$ together with nitrate concentrations exceeding $50 \mathrm{mg} / \mathrm{L}$ was used to identify the fertilizer-borne input of nitrate. However, the factor controlling Mn occurrence seemingly was the depth of monitoring wells and the screen-length. Elevated concentrations of $\mathrm{Mn}$ and a high $\Delta \mathrm{Mn}$-Fe were generally found in shallow wells and wells with short screen-lengths.
\end{abstract}

Keywords: Manganese; iron; background concentration; redox environment; land use

\section{Introduction}

The two redox-sensitive transition metals manganese $(\mathrm{Mn})$ and iron $(\mathrm{Fe})$ are included in most groundwater monitoring programs and their concentration is directly related to redox reactions. Both are more or less insoluble in their oxidized state and thus, are only present in groundwater under reducing conditions. In anoxic environments $\mathrm{Mn}$ and Fe can be found at elevated concentrations, because they are released from their respective oxides, which are commonly present in the aquifer matrix [1]. Along the vertical and horizontal paths of water movement in the aquifer, the degradation of organic matter forms a sequence of redox zones from oxygenated near the surface to more reducing conditions at depth. This concept of redox stratification was described by several authors, e.g., [2-5]. In this sequence $\mathrm{Mn}(\mathrm{IV})$ is reduced first, but then immediately followed by the reduction of Fe(III), e.g., [4]. While elevated concentrations of Fe are generally not of any health concern, elevated concentrations of $\mathrm{Mn}$ in drinking water may pose a serious health threat [6-8]. Surprisingly, no single country nor the World Health Organization (WHO) has established a maximum contamination level (MCL) for Mn. In the United States, there is a "non-enforced" $300 \mu \mathrm{g} / \mathrm{L}$ health reference level for Mn and McMahon et al. [1] found that Mn concentrations were above that value in $6.9 \%$ of samples collected as part of a national groundwater study in the United States and they estimated that 2.6 million people potentially consume groundwater with elevated Mn concentrations. 
While Mn and Fe are the two most abundant transition metals in the continental crust, Fe still exceeds Mn by a factor of up to 60 [9]. Hence it could be surmised that the concentration of $\mathrm{Fe}$ in groundwater should be substantially higher than that of Mn. Wendland et al. [10] who studied groundwater composition at the European scale found that, in groundwater from unconfined glacial sand and gravel aquifers, the median concentration of Fe was up to 20-times higher than of Mn. Nevertheless, in several instances and in similar hydrogeological settings the opposite was observed, i.e., the concentration of $\mathrm{Mn}$ was higher than the concentration of Fe [11]. Jones et al. [12] described the phenomenon of Mn exceeding the Fe concentration on a centimeter-scale in lab experiments in natural sandy loam, while Bjerg et al. [3] and Droll and Isenbeck-Schröter [13] showed that, in groundwater, the zone where the concentration of Mn exceeds that of Fe can be up to one meter. Theoretically, Mn concentrations exceeding those of Fe should only be possible in the upper part of the Mn reduction zone, particularly in the presence of nitrate, which oxidizes Fe. Koopmann et al. [11] demonstrated this in a series of batch experiments, showing that, in the presence of nitrate only, the concentration of Mn increased, while in the same experiment without addition of nitrate both $\mathrm{Mn}$ and Fe increased. They concluded that nitrate input into shallow aquifers should have a decisive influence on the Fe/Mn ratios in groundwater. According to their findings, a close evaluation of $\mathrm{Mn}$ and Fe concentrations in groundwater could serve as an interesting indicator of groundwater "health" with respect to the diffuse fertilizer-borne input of nitrate on agricultural land.

The goal of this study was to provide added information about the occurrence of elevated Mn concentrations in groundwater through evaluation of a large hydrogeochemical data set. We analyzed a dataset for northern Germany, a region that is dominated by agriculture and relatively uniform (hydro)geology combined with accessible data on groundwater quality from several monitoring programs. In detail, we calculated background values for $\mathrm{Mn}$ and Fe in groundwater to determine geogenic concentrations and compared land use to Mn concentrations. In a part of the study area, Mn time series were investigated to verify changes in the groundwater composition and potentially land use over time.

\section{Geology and Hydrogeology of the Study Area}

The study area is comprised of quaternary sediments in northern Germany covering most of the federal states of Lower Saxony and Bremen (Figure 1). It extends over approximately $40,000 \mathrm{~km}^{2}$ and is separated into four hydrogeological units: islands, tidal wetlands, Geesten and fluviatile lowlands. Both, islands and tidal wetlands were formed predominantly by the North Sea. Lowlands developed along rivers and creeks, while the Geesten were deposited during the Pleistocene and mainly consist of glacio-fluvial sediments. As mostly unconfined upper aquifers, they represent groundwater recharge areas as well as catchment areas for water supply [14]. The four hydrogeological units can be divided further into subareas (Figure 1), which are of a homogeneous structure with respect to natural areas and topographical borders [14].

There are differences between the hydrogeological units and hence the groundwater chemistry varies within the study area. However, due to a relatively uniform geology, which is dominated by glacial sands variations between the hydrogeological units are rather small. Groundwater from the islands mainly occurs as the bicarbonate predominated alkaline-earth type, while groundwater from the tidal wetlands is mainly Fe- and sulfate reducing and belongs to the group of alkaline waters with decreasing bicarbonate contents. Groundwater in the lowlands and the Geesten is predominantly of the alkaline-earth type with lower bicarbonate contents. Groundwater in the uplands appears to be oxic and was labeled as bicarbonate dominated and bicarbonatic-sulfatic alkaline-earth [15].

The main land use in the study area is arable land $(46 \%)$, followed by forest area $(22 \%)$, grassland $(21 \%)$, and urban areas (7\%) [16]. 

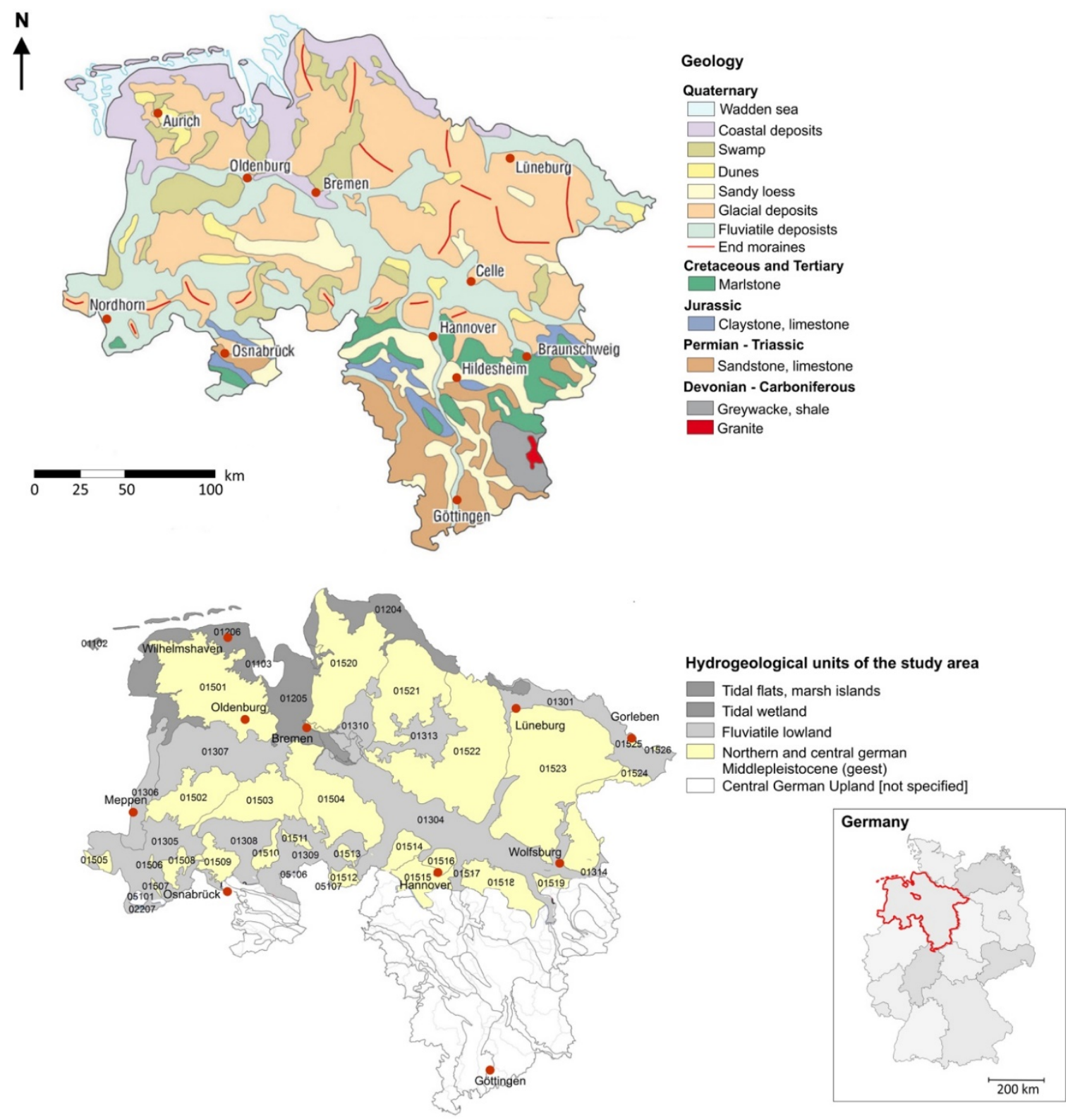

Figure 1. Geology of Lower Saxony and hydrogeological units of the study area in Northwestern Germany with respective subareas represented by code numbers (modified from Elbracht et al., 2016 and Heunisch et al., 2017).

\section{Data and Methods}

The entire dataset consists of approximately 32,000 chemical groundwater analyses from more than 4800 monitoring wells that were collected between 1957 and 2015 within the frame of the European Water Framework Directive [17] and the groundwater directive [18]. Point-source contaminations are not part of this data set, because possible point sources are investigated in operational monitoring nets, which separate from the comprehensive WFD-monitoring net. The data set was compiled from the federal database maintained by the Niedersächsischer Landesbetrieb für Wasserwirtschaft, Küstenund Naturschutz (NLWKN), the Landesamt für Bergbau, Energie und Geologie (LBEG), the Senator für Umwelt, Bau und Verkehr (SUBV) of Bremen and the City of Hannover, representing the water management and geological surveys of Lower Saxony and Bremen. A standardized plausibility check 
in the form of a charge balance calculation was applied for each sample and only samples with a deviation better than $5 \%$ were used.

The data set included the parameters $\mathrm{pH}$, redox potential, $\mathrm{Na}^{+}, \mathrm{K}^{+}, \mathrm{Ca}^{2+}, \mathrm{Mg}^{2+}, \mathrm{SO}_{4}{ }^{2-}, \mathrm{Cl}^{-}$, $\mathrm{HCO}_{3}{ }^{-}, \mathrm{NO}_{3}{ }^{-}, \mathrm{Fe}, \mathrm{Mn}, \mathrm{PO}_{4}{ }^{3-}$, and $\mathrm{Zn}$. In detail, groundwater was sampled after the field parameters of temperature, electric conductivity, $\mathrm{pH}$-value, and oxygen content were constant. The samples were filtrated through $0.45 \mu \mathrm{m}$ membrane filters and separated in subsamples. Subsamples for cation analyses were acidified to a $\mathrm{pH}$-value $<2$ with nitric acid. Analytical technics were applied, which offered a detection limited of less than $30 \%$ of the respective threshold value or criteria of interest. During statistical analyses those elemental concentrations that were below the limit of detection were represented as half the value of the detection limit (e.g., [19]).

The boundaries of the hydrogeological units were based on the hydrogeological map of Germany at the scale of 1:200,000 (HÜK200; recent map: HÜK250), provided by the German Federal Institute for Geosciences and Natural Resources [20]. In order to identify the respective land use for the monitoring wells, the digital land cover "CORINE Land Cover 10 ha (CLC10)" was used [16].

\subsection{Statistical Methods}

The sampling points were classified according to their respective hydrogeological units and associated land use with the geographic information system (GIS) package ArcGIS [21].

The basic statistical analyses are a quantitative and independent approach of aqueous geochemical classification and description allowing the correlation between chemical parameters. Since the distributions of most chemical parameters (in $\mathrm{mg} / \mathrm{L}$ ) show a bimodal and left skewed distribution according to the Kolmogorov-Smirnov test at a significant level with $p$-value $\leq(\alpha=0.05)$, only the application of non-parametric tests such as the Spearman's correlation analyses and the Mann-Kendall-test were used.

The non-parametric measure of Spearman's rank was applied to calculate the degree of statistical dependency of $\mathrm{Mn}, \mathrm{Fe}$, and $(\Delta \mathrm{Mn}-\mathrm{Fe})$ on other redox-sensitive or arable land use-related parameters ( $p$-value $\leq(\alpha=0.01)$ ). A correlation coefficient ranges between $\mathrm{rs}=+/-1$ and consequently, absolute values of $0.8<\mathrm{rs} \leq 1$ indicate a strong correlation, whereas $0.5<\mathrm{rs} \leq 0.8$ describes an intermediate to strong correlation, while $\mathrm{rs}=0$ would indicate an absolute independency between the variables, e.g., $[22,23]$.

Prior to the test and except for the $\mathrm{pH}$-value, the data were log-transformed to attain a normal distribution by calculating their standard scores and generate their comparability with $\mathrm{x}=$ value of sample, $\mu=$ mean and $\delta=$ standard derivation as follows, e.g., [24,25].

Time-based concentration trends for Fe and Mn were tested with the Mann-Kendall trend test. This test requires a minimum number of 4 values per monitoring well and was applied for 224 wells with concentrations above detection limit in the southwest of the study area (hydrogeological subareas: 01305 and 01502, 01503, 01508; Figure 1).

\subsection{Derivation of Background Concentrations for $\mathrm{Mn}$}

In order to calculate the background concentration for $\mathrm{Mn}$ in the study area, all $\mathrm{Mn}$ analyses of the observation wells were used. The outliers at the top and bottom of the data set were identified in a probability plot and excluded in order to approach a log-normal distribution of Mn concentration within a given hydrogeological unit [26,27]. In the case of more than ten available analyses, the 90th percentile was set as the natural background for $\mathrm{Mn}$ in the respective hydrogeological unit or subarea.

\section{3. $M n$-Fe-Difference $\left(\Delta_{M n-F e}\right)$}

A new parameter, $\Delta_{\mathrm{Mn}-\mathrm{Fe}}$, defined as the concentration difference between $\mathrm{Mn}$ and $\mathrm{Fe}$ in $\mathrm{mg} / \mathrm{L}$ $\left(\Delta_{\mathrm{Mn}-\mathrm{Fe}}=\mathrm{Mn} \mathrm{mg} / \mathrm{L}-\mathrm{Fe} \mathrm{mg} / \mathrm{L}\right)$, was used to describe the Mn-Fe relationship in the study area. This parameter is purely empirical. It was used to identify groundwaters, which compared to Fe have a relatively high $\mathrm{Mn}$ concentration. A $\Delta_{\mathrm{Mn}-\mathrm{Fe}}>0$, for example, indicates that the Mn concentration in a 
sample is greater than the concentration of $\mathrm{Fe}$, which was thought-provoking, considering that $\mathrm{Fe}$ is present at a much higher concentration in the aquifer matrix, e.g., [9]. Due to their almost identical atomic masses, we opted to use $\mathrm{mg} / \mathrm{L}$ rather than molar units.

\section{Results}

\subsection{Groundwater Analyses}

The 50th and 90th percentile concentrations for all parameters, which were evaluated in this study are listed in Table 1. The concentrations are separated into their hydrogeological units, i.e., tidal wetlands, Geesten, and fluvatile lowlands. The respective median Fe and Mn concentrations in tidal wetlands were 4.83 and $0.46 \mathrm{mg} / \mathrm{L}$, in fluviatile lowlands 5.40 and $0.27 \mathrm{mg} / \mathrm{L}$ and in the Geesten 0.67 and $0.12 \mathrm{mg} / \mathrm{L}$ (Figure 2A). Separating the data by land use the median concentrations for Fe and Mn were 1.81 and $0.20 \mathrm{mg} / \mathrm{L}$ for arable land, 1.54 and $0.15 \mathrm{mg} / \mathrm{L}$ for forests and 3.80 and $0.24 \mathrm{mg} / \mathrm{L}$ for grassland (Figure 2B). In total, more than $40 \%$ of the samples had Mn concentrations above the "non-enforced" $300 \mu \mathrm{g} / \mathrm{L}$ Health Reference Level put forth by the U.S. The highest concentration of $\mathrm{Mn}$ in the dataset was $620 \mathrm{mg} / \mathrm{L}$ and in 29 samples the concentration was above $10 \mathrm{mg} / \mathrm{L}$. The highest concentration of Fe in the dataset was $394 \mathrm{mg} / \mathrm{L}$ and in 164 samples the concentration was above 50 $\mathrm{mg} / \mathrm{L}$. Thus, more than $99 \%$ of samples had Mn concentration below $10 \mathrm{mg} / \mathrm{L}$ and Fe concentrations below $50 \mathrm{mg} / \mathrm{L}$. Only those samples that fell into that range were further evaluated in the study.

Table 1. Total analysis number $\left(n^{a}\right)$, 50th and 90th percentile concentration within each hydrogeological unit.

\begin{tabular}{|c|c|c|c|c|c|c|c|c|c|}
\hline \multirow[b]{2}{*}{ Parameter ${ }^{1}$} & \multicolumn{3}{|c|}{ Tidal Wetlands } & \multicolumn{3}{|c|}{ Geesten } & \multicolumn{3}{|c|}{ Fluviatile Lowlands } \\
\hline & $n^{a}$ & 50th & 90th & $n^{a}$ & 50th & 90th & $n^{a}$ & 50th & 90th \\
\hline $\mathrm{K}^{+}$ & 2375 & 7 & 36.00 & 13,713 & 3.2 & 17 & 10,947 & 3.10 & 18 \\
\hline $\mathrm{Na}^{+}$ & 2374 & 65.8 & 1200 & 13,371 & 15 & 32 & 10,630 & 17.00 & 60 \\
\hline $\mathrm{NH}_{4}{ }^{+}$ & 1821 & 1.8 & 19 & 13,990 & 0.04 & 0.5 & 10,501 & 0.27 & 2.58 \\
\hline $\mathrm{Ca}^{2+}$ & 2396 & 68 & 210 & 13,907 & 36 & 92 & 11,187 & 43 & 102 \\
\hline $\mathrm{Fe}$ & 2398 & 4.83 & 34 & 14,397 & 0.67 & 10.2 & 11,417 & 5.40 & 20.5 \\
\hline $\mathrm{Mg}^{2+}$ & 2401 & 14.8 & 96 & 13,912 & 5.6 & 15 & 11,094 & 5.7 & 14 \\
\hline Mn & 2448 & 0.46 & 3.4 & 14,965 & 0.12 & 0.51 & 12,041 & 0.27 & 0.94 \\
\hline $\mathrm{Zn}$ & 865 & 0.01 & 0.07 & 3728 & 0.02 & 0.09 & 2785 & 0.02 & 0.09 \\
\hline $\mathrm{Al}^{3+}$ & 1315 & 0.02 & 0.16 & 9317 & 0.03 & 1.09 & 7442 & 0.04 & 1 \\
\hline $\mathrm{Cl}^{-}$ & 2438 & 93 & 2066 & 14,552 & 30.8 & 64 & 11,873 & 34.00 & 107 \\
\hline $\mathrm{NO}_{3}^{-}$ & 2421 & 0.22 & 2.99 & 14,603 & 4 & 106 & 11,678 & 0.50 & 58,4 \\
\hline $\mathrm{NO}_{2}^{-}$ & 2123 & 0.02 & 0.05 & 13,851 & 0.02 & 0.03 & 10,077 & 0.02 & 0.04 \\
\hline $\mathrm{HCO}_{3}^{-}$ & 2386 & 238 & 805 & 13,837 & 30.5 & 198 & 11,350 & 75.66 & 242 \\
\hline $\mathrm{SO}_{4}^{2-}$ & 2393 & 14 & 177 & 14,781 & 48 & 112 & 11,903 & 56.00 & 149 \\
\hline $\mathrm{PO}_{4}^{3-}$ & 721 & 0.46 & 5.25 & 3289 & 0.16 & 1.2 & 3154 & 0.24 & 1.37 \\
\hline $\mathrm{BO}_{3}^{-}$ & 126 & 0.5 & 5.10 & 580 & 0.06 & 0.27 & 450 & 0.08 & 0.49 \\
\hline $\mathrm{O}_{2}$ & 1960 & 0.2 & 1.40 & 12,775 & 1.7 & 9.1 & 9448 & 0.52 & 4.3 \\
\hline $\mathrm{CH}_{4}$ & 58 & 0.03 & 0.06 & 227 & 0.03 & 0.03 & 181 & 0.03 & 0.66 \\
\hline B & 283 & 0.08 & 1.11 & 1785 & 0.03 & 0.09 & 2029 & 0.03 & 0.14 \\
\hline DOC & 1291 & 6.6 & 22.9 & 7800 & 1.6 & 7.2 & 6050 & 4.1 & 19 \\
\hline $\mathrm{N}_{2}$ surplus & 78 & 0.25 & 6,27 & 402 & 2.87 & 12.4 & 289 & 4.56 & 14.6 \\
\hline $\mathrm{pH}$ value & 2381 & 6.8 & 8.03 & 14,473 & 6 & 7.4 & 11,829 & 6.3 & 7.3 \\
\hline conductivity & 1844 & 825 & 10,474 & 12,519 & 394 & 670 & 10,319 & 420 & 880 \\
\hline red. potential & 224 & 90 & 190 & 1045 & 250 & 540.4 & 1382 & 143 & 367 \\
\hline temperature & 1808 & 10.7 & 12.50 & 11,685 & 10 & 11 & 9844 & 10.3 & 11.7 \\
\hline tot. hardness & 218 & 2.77 & 19.95 & 1664 & 1.25 & 2.7 & 1304 & 1.30 & 3.3 \\
\hline
\end{tabular}

${ }^{1}$ Chemical concentration is in $\mathrm{mg} / \mathrm{L}$, conductivity in $\mathrm{mS} / \mathrm{cm}$, redox potential in $\mathrm{mV}$, temperature in ${ }^{\circ} \mathrm{C}$. 
(A)
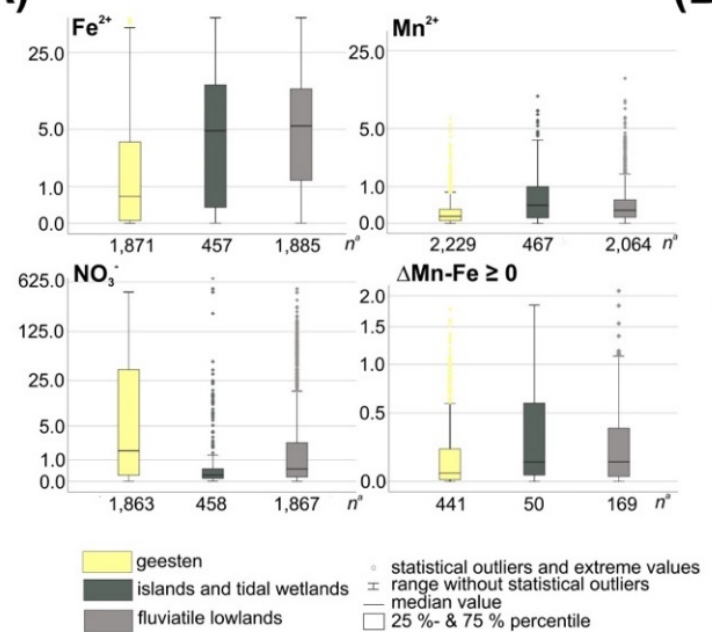

(B)
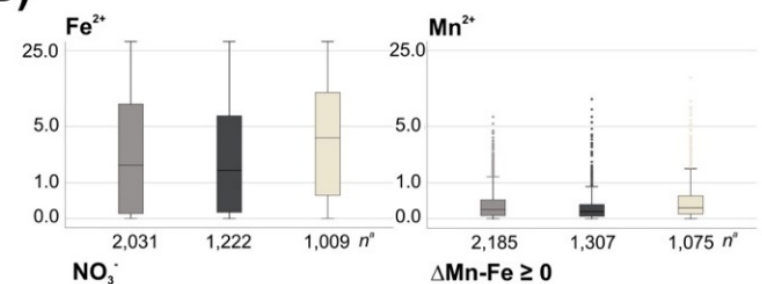

$\Delta \mathrm{Mn}-\mathrm{Fe} \geq 0$
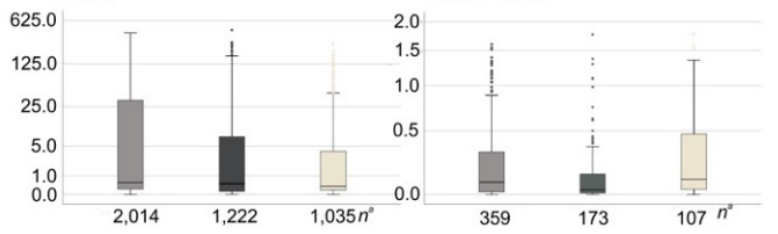

\begin{tabular}{|l|}
\hline arable land \\
forest area \\
grassland
\end{tabular} statistical outliers and extreme values statistical outliers and extreme valu
range without statistical outliers

Figure 2. (A) Rank statistical distribution of $\mathrm{Fe}, \mathrm{Mn}$, nitrate and $\Delta_{\mathrm{Mn}-\mathrm{Fe}} \geq 0$ in the hydrogeological units. (B) Rank statistical distribution of Fe, Mn, nitrate and $\Delta_{\mathrm{Mn}-\mathrm{Fe}} \geq 0$ grouped by land use. The $x$-axis indicates the number of recent analyses per unit. The numbers differ because not all parameter were analyzed in every sample, the $y$-axis indicates the concentration $[\log \mathrm{mg} / \mathrm{L}]$. The $\Delta_{\mathrm{Mn} \text {-Fe }}$ values are only given for $\Delta_{\mathrm{Mn}-\mathrm{Fe}}>0$.

The interquartiles ( $25 \%$ to $75 \%$ ) in the hydrogeological units for Fe were quite large, while those for Mn were comparatively less. The number of statistical outliers and extreme values was much higher for Mn (Figure 2). The Geesten had the smallest interquartile range and lowest median concentrations for $\mathrm{Mn}$ and Fe. The concentration of nitrate in the Geesten on the other hand was the highest with the largest interquartile range. With respect to land use, i.e., forest, agriculture, and pasture the median Mn concentrations were $0.18,0.24$ and $0.19 \mathrm{mg} / \mathrm{L}$, respectively.

The parameter $\Delta_{\mathrm{Mn}-\mathrm{Fe}}$ with a very few exceptions ranged from $>-100$ to $<40$, and only 30 analyses out of the whole dataset did not fall into that range. The value was in most analyses negative expressed by the respective percentiles 10 th percentile at -20.1 , 25th percentile -11.3 , median at -4.6 , and 75 th percentile at -1.3 (660 analyses showed a positive $\Delta_{\mathrm{Mn} \text {-Fe }}$ (Figure 2 ).

Nitrate showed a wide range of concentrations (median $=1.68,0.21$, and $0.49 \mathrm{mg} / \mathrm{L}$ in appropriate order of hydrogeological units (Figure 2) with interquartile ranges of 33.81, 0.51, and $2.35 \mathrm{mg} / \mathrm{L}$ ).

\subsection{Spearman's Rank Correlation}

The Spearman's rank correlation analyses were performed for Mn, Fe and $\Delta_{\mathrm{Mn} \text {-Fe }}$ for the same hydrogeological units as above with respect to further parameter (Table 2). The correlations of Mn showed an intermediate coefficient to Fe in all units, and relatively high correlation levels were given with ammonium and $\Delta_{\mathrm{Mn}-\mathrm{Fe}} \geq 0$, as well as hydrogen carbonate and chloride in tidal wetlands respectively fluviatile lowlands (Table 2).

Correlation with respect to Fe showed high positive coefficients to $\mathrm{Mn}, \Delta_{\mathrm{Mn}-\mathrm{Fe}}$ and a negative to nitrate, while correlations with respect to $\Delta_{\mathrm{Mn}-\mathrm{Fe}}>0$ were positive to $\mathrm{Mn}$, weaker positive to $\mathrm{Fe}$, and positive to nitrate except of the tidal wetlands. 
Table 2. Spearman's Rank Correlation for Mn, Fe and $\Delta_{\mathrm{Mn}-\mathrm{Fe}}>0$ with additional hydrogeochemical parameters for the most recent analyses from each well, grouped by hydrogeological unit ${ }^{1}$.

\begin{tabular}{|c|c|c|c|}
\hline Parameter & $\begin{array}{c}\text { Tidal } \\
\text { Wetland }\end{array}$ & Geest & $\begin{array}{c}\text { Fluviatile } \\
\text { Lowland }\end{array}$ \\
\hline Mn & 1.00 & 1.00 & 1.00 \\
\hline $\mathrm{Fe}$ & 0.66 & 0.59 & 0.55 \\
\hline$\Delta_{\mathrm{Mn}-\mathrm{Fe}} \geq 0$ & 0.91 & 0.89 & 0.41 \\
\hline $\mathrm{pH}$ & 0.33 & 0.12 & 0.20 \\
\hline $\mathrm{O}_{2}$ & 0.10 & -0.37 & -0.13 \\
\hline $\mathrm{SO}_{4}^{2-}$ & -0.06 & 0.17 & -0.40 \\
\hline $\mathrm{NO}_{3}{ }^{-}$ & -0.06 & -0.30 & -0.09 \\
\hline $\mathrm{NH}_{4}^{+}$ & 0.69 & -0.53 & 0.40 \\
\hline $\mathrm{Fe}$ & 1.00 & 1.00 & 1.00 \\
\hline $\mathrm{Mn}$ & 0.66 & 0.47 & 0.51 \\
\hline$\Delta_{\mathrm{Mn}-\mathrm{Fe}} \geq 0$ & 0.46 & 0.26 & 0.27 \\
\hline $\mathrm{pH}$ & -0.49 & 0.28 & 0.09 \\
\hline $\mathrm{O}_{2}$ & -0.02 & -0.59 & -0.33 \\
\hline $\mathrm{SO}_{4}^{2-}$ & -0.06 & 0.02 & 0.11 \\
\hline $\mathrm{NO}_{3}{ }^{-}$ & -0.28 & -0.63 & -0.51 \\
\hline $\mathrm{NH}_{4}{ }^{+}$ & 0.51 & 0.56 & 0.62 \\
\hline$\Delta_{\mathrm{Mn}-\mathrm{Fe}} \geq 0$ & 1.00 & 1.00 & 1.00 \\
\hline $\mathrm{Mn}$ & 0.86 & 0.9 & 0.9 \\
\hline $\mathrm{Fe}$ & 0.46 & 0.26 & 0.27 \\
\hline $\mathrm{pH}$ & -0.38 & -0.38 & -0.13 \\
\hline $\mathrm{O}_{2}$ & -0.09 & -0.14 & -0.24 \\
\hline $\mathrm{SO}_{4}^{2-}$ & 0.39 & 0.18 & 0.25 \\
\hline $\mathrm{NO}_{3}^{-}$ & -0.12 & 0.23 & 0.15 \\
\hline $\mathrm{NH}_{4}{ }^{+}$ & 0.61 & 0.01 & 0.21 \\
\hline
\end{tabular}

${ }^{1}$ The stochastic relations were described by spearman's correlation coefficient $r_{s}$. Marked in grey if the statistical significance level of $\alpha=0.01$ was not reached.

\subsection{Trend Analyses}

Mann-Kendall-trend tests for Fe and Mn of 224 piezometers in four hydrogeological subunits (code numbers 01305, 01502, 01503, 01508) of the southern region of Weser-Ems were analyzed. The time series were defined into increasing, decreasing trends and absence of discernible trends, i.e., no trends (Table 3).

Table 3. Matrix of time series data for Fe and Mn in monitoring wells in the Weser-Ems area.

\begin{tabular}{cccc}
\hline Fe Mn & $\begin{array}{c}\text { Increasing } \\
\boldsymbol{n = 4 5}\end{array}$ & $\begin{array}{c}\text { Decreasing } \\
\boldsymbol{n}=\mathbf{5 4}\end{array}$ & $\begin{array}{c}\text { No Trend } \\
\boldsymbol{n}=\mathbf{1 2 5}\end{array}$ \\
\hline $\begin{array}{c}\text { increasing } \\
n=62\end{array}$ & 31 & 8 & 23 \\
\hline $\begin{array}{c}\text { decreasing } \\
n=44\end{array}$ & 5 & 28 & 11 \\
\hline $\begin{array}{c}\text { no trend } \\
n=118\end{array}$ & 9 & 18 & 91 \\
\hline
\end{tabular}

About half of the analyzed monitoring wells showed trends, which were more or less evenly split into increasing and decreasing trends (Table 3). The same was observed for Fe trends as well. Fe was predominantly decreasing in the fluviatile lowlands and without a trend in the Geesten. Conversely, of 54 tests with decreasing Mn conditions, $26 \mathrm{Fe}$ analyses (48\%) were found with non-decreasing conditions. In those cases, Fe was mostly increasing in the fluviatile lowlands, in all other cases a distinct regional classification could not be executed. 


\subsection{Background Values}

The calculated Mn background values ranged from less than $0.25 \mathrm{mg} / \mathrm{L}$ to more than $2.43 \mathrm{mg} / \mathrm{L}$ (Figure 3) and were classified within three categories: Lowest concentrations up to $0.5 \mathrm{mg} / \mathrm{L}$ in the main (NW-SE striking) ridges of the Geesten and most of smaller moraine areas in the south of Lower Saxony, median concentrations up to $1 \mathrm{mg} / \mathrm{L}$ in the Geesten 01501,01520, 01515-01518, and most of fluviatile lowland areas and the highest concentrations in the tidal wetlands and fluviatile lowland areas 01304 and 01310 . The tidal wetlands 01204 and 01205 had background concentrations with values above $2.43 \mathrm{mg} / \mathrm{L}$.

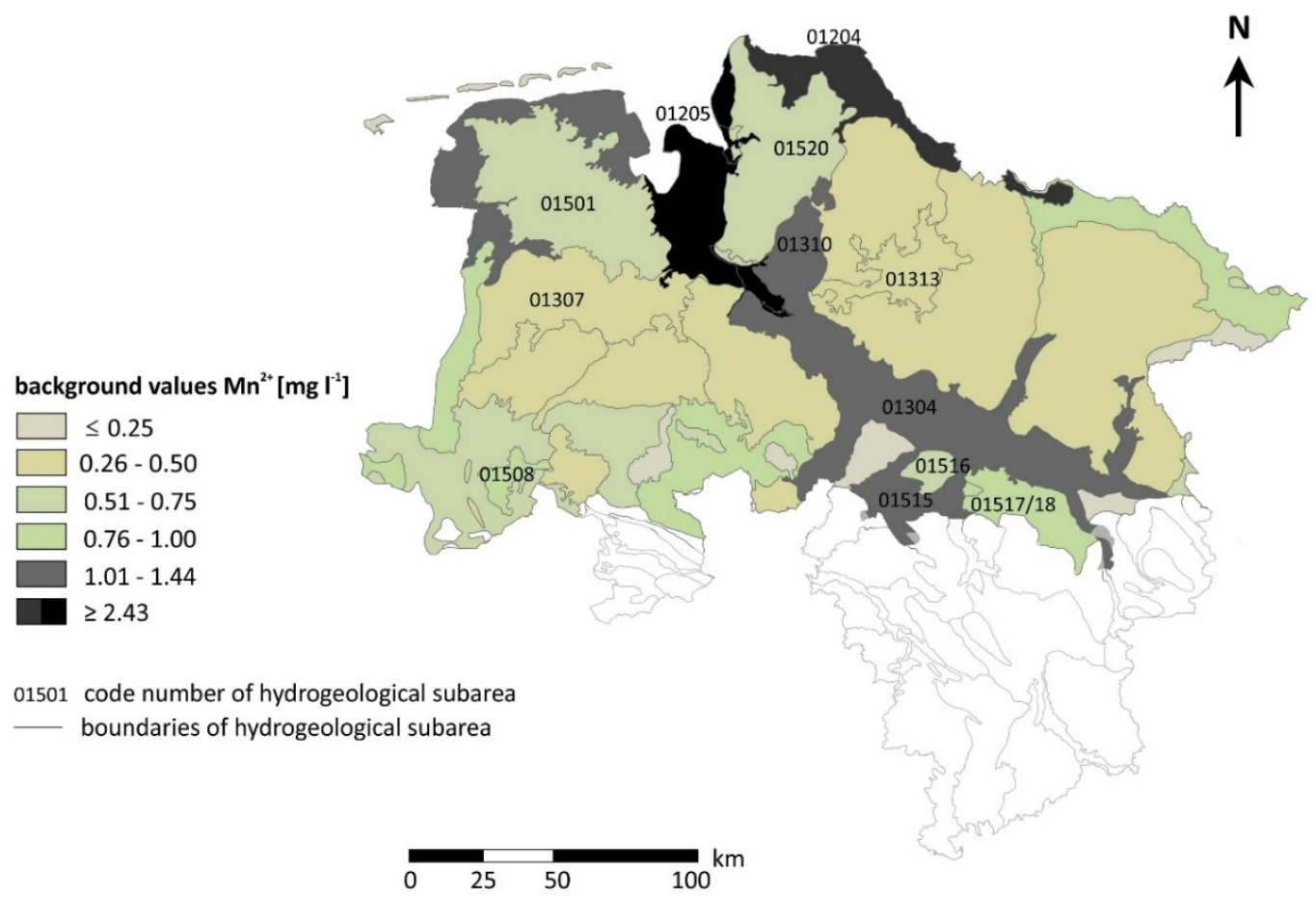

Figure 3. Results of the derivation of background values for Mn in 37 hydrogeological subareas with code numbers (e.g., 01307). The background values were classified into six ranges of concentration with the tidal wetlands being assigned extreme values $\geq 2.43$.

\section{Discussion}

Although the potential toxicological effects of $\mathrm{Mn}$ are still being discussed, the number of recent studies that documented adverse health effects is disconcerting, e.g., [28]. Kullar et al. [29] who studied the effect of Mn on the IQ of children, computed weight averaged median estimates for the benchmark concentration (BMC) of Mn in drinking water and discovered the first adverse effects at $0.133 \mathrm{mg} / \mathrm{L}$. It is conceivable that there is only limited interest in the regulation of Mn in drinking water, because it is more or less completely removed during drinking water treatment, although the motivation is typically driven by aesthetic and potential distribution system issues, rather than public health concerns [30]. Thus, households connected to a centralized water distribution system are not exposed to elevated concentrations. While in most developed countries the majority of households are connected to centralized systems, there are still rural areas where private domestic supply wells are utilized for drinking water supply. Domestic supply wells, if not tested regularly, can pose a surreptitious threat to human health, e.g., [31,32].

The surficial groundwater in the study area showed a wide range of Mn concentrations (Figure 3) and it was surprising to find that more than $40 \%$ of the samples had concentrations above $0.3 \mathrm{mg} / \mathrm{L}$. Due to the absence of data for potential point-source contamination, such as mines and tanneries, e.g., [33,34] elevated Mn concentrations in the study area should be of geogenic origin and released 
form the aquifer matrix due to changing physicochemical conditions [35]. Manganese is a relatively common element in the Earth's crust and thus should be present in the aquifer matrix at concentrations sufficient to account for the observed aqueous Mn concentrations.

In general, Mn concentrations are expected to be below those of Fe because the average Fe content in the upper crust exceeds that of $\mathrm{Mn}$ by a factor of 60 [9]. Commonly, that applies to groundwater as well, e.g., [10], and was confirmed for the majority of samples in the study. However, there were many monitoring wells, where Mn was present at a higher concentration than Fe. Applying the criteria of Bjerg et al. [3] and Christensen et al. [4] approximately 24,000 of the samples were collected from the Mn reduction zone and among those approximately 19,000 were simultaneously Fe reducing. Of those, 1075 analyses from 660 monitoring wells had a positive $\Delta_{\mathrm{Mn}-\mathrm{Fe}}$, identifying them as anomalous as per our definition (see Section 3.3.). Of those, 746 analyses showed an indication for nitrate reduction at the same time (Table 4).

Table 4. Number of analyses in showing denitrification, Mn-, and Fe- reduction, partly simultaneously.

\begin{tabular}{ccc}
\hline Number of Analyses & Redox Environment & Criterion \\
\hline 23,779 of 31,946 & Mn reduction & $\mathrm{Mn}>0.05 \mathrm{mg} / \mathrm{L}$ \\
\hline \multirow{2}{*}{18,966 of 23,779 } & Mn and Fe-reduction & $\mathrm{Mn}>0.05 \mathrm{mg} / \mathrm{L}$ and \\
& $\mathrm{Fe}>0.1 \mathrm{mg} / \mathrm{L}$ \\
\hline \multirow{2}{*}{1079 of 18,966} & Mn and Fe-reduction with Mn exceeding & $\mathrm{Mn}>0.05 \mathrm{mg} / \mathrm{L}$, \\
& Fe concentration & $\mathrm{Fe}>0.1 \mathrm{mg} / \mathrm{L}$ and \\
& & $\Delta_{\mathrm{Mn}-\mathrm{Fe}} \geq 0$ \\
\hline & & $\mathrm{Mn}>0.05 \mathrm{mg} / \mathrm{L}$, \\
& & $\mathrm{Fe}>0.1 \mathrm{mg} / \mathrm{L}$, \\
& Mn and Fe-reduction with Mn exceeding & $\Delta_{\mathrm{Mn}-\mathrm{Fe}} \geq 0$ \\
& Fe concentration with denitrification & and $\mathrm{NO}_{3}>2.2 \mathrm{mg} / \mathrm{L}$ \\
\hline
\end{tabular}

From a geochemical perspective as a starting point, both metals are mobilized into groundwater in the course of different redox reactions in their respective redox environments, e.g., [3,4]. These environments are the result of a succession of electron accepting processes degrading organic matter or oxidizing minerals such as pyrite. This succession of processes tends to segregate into zones [36]. Close to the groundwater table, toxic conditions prevail followed by the zone of denitrification where either organic matter or pyrite are oxidized. That zone is followed first by the Mn- and then the Fe-reduction zone where the following reactions take place:

$$
\begin{aligned}
& \mathrm{CH}_{2} \mathrm{O}+2 \mathrm{MnO}_{2}+4 \mathrm{H}^{+} \rightarrow 2 \mathrm{Mn}^{2+}+\mathrm{CO}_{2}+3 \mathrm{H}_{2} \mathrm{O} \\
& \mathrm{CH}_{2} \mathrm{O}+4 \mathrm{FeOOH}+8 \mathrm{H}^{+} \rightarrow 4 \mathrm{Fe}^{2+}+\mathrm{CO}_{2}+7 \mathrm{H}_{2} \mathrm{O}
\end{aligned}
$$

causing first the appearance of $\mathrm{Mn}$ before Fe. This phenomenon, however, has a small spatial extension and was only observed in high-resolution sampling studies. Jones et al. [12] described higher Mn than Fe concentration in a cm scale within sandy loam in lab experiments while other authors measured in groundwater a range of several $\mathrm{dm}$ up to a meter [3,13]. Thus, we believe that the empirical parameter $\Delta_{\mathrm{Mn}-\mathrm{Fe}}$ could serve as indicator for the identification of the upper part of the Mn reducing zone (Figure 4). The decision that anomalies are defined as $\Delta_{\mathrm{Mn}-\mathrm{Fe}}>0$ was taken completely arbitrarily, although it seems to work for this dataset. Depending on regional, land use, geological, and hydrogeological conditions, this definition may have to be adjusted.

At first glance the parallel appearance of denitrification, Mn- and Fe-reduction seemed to be in discrepancy with the concept of separate redox zones. In the end, however, this observation should be a consequence of sampling different redox environments simultaneously. Particularly since ground-water samples are often mixtures of water from multiple parts of an aquifer that have different redox conditions, e.g., [37]. In addition, the monitoring net in the study area was designed to sample 
shallow groundwater, however, many monitoring wells have well screens too long to allow for the sampling of a discrete redox zone. A wide range of the length of the screens in the sampled monitoring wells was applied (Figure 5) which led to mixed redox environments during sampling. Only 3.6\% of the monitoring wells had screen lengths of less than $1 \mathrm{~m}$ and only $31 \%$ of the screens were less than $2 \mathrm{~m}$ (Figure 5). The influence of screen length and position with respect to the groundwater table on the analysed groundwater quality was illustrated by Wriedt and Randt [38] when they tried to explain the regional distribution of phosphate concentration in the upper aquifer in our study area in Lower Saxony. Their statistical approach was based on principal component analysis and made obvious that phosphate concentrations in surficial groundwater were influenced by redox conditions. It was possible to qualitatively assess that higher concentrations of Mn were measured in samples collected from monitoring wells with shorter screen lengths (Figure 6). Once screen length was above $5 \mathrm{~m}$, Mn concentrations dropped to about $2 \mathrm{mg} / \mathrm{L}$ or less. While not as evident as for the screen lengths, the screen depth (below surface) showed a qualitatively inverse relationship with $\mathrm{Mn}$ concentration (Figure 6), demonstrating the greater susceptibility of shallow groundwater for elevated Mn concentrations, e.g., [39].

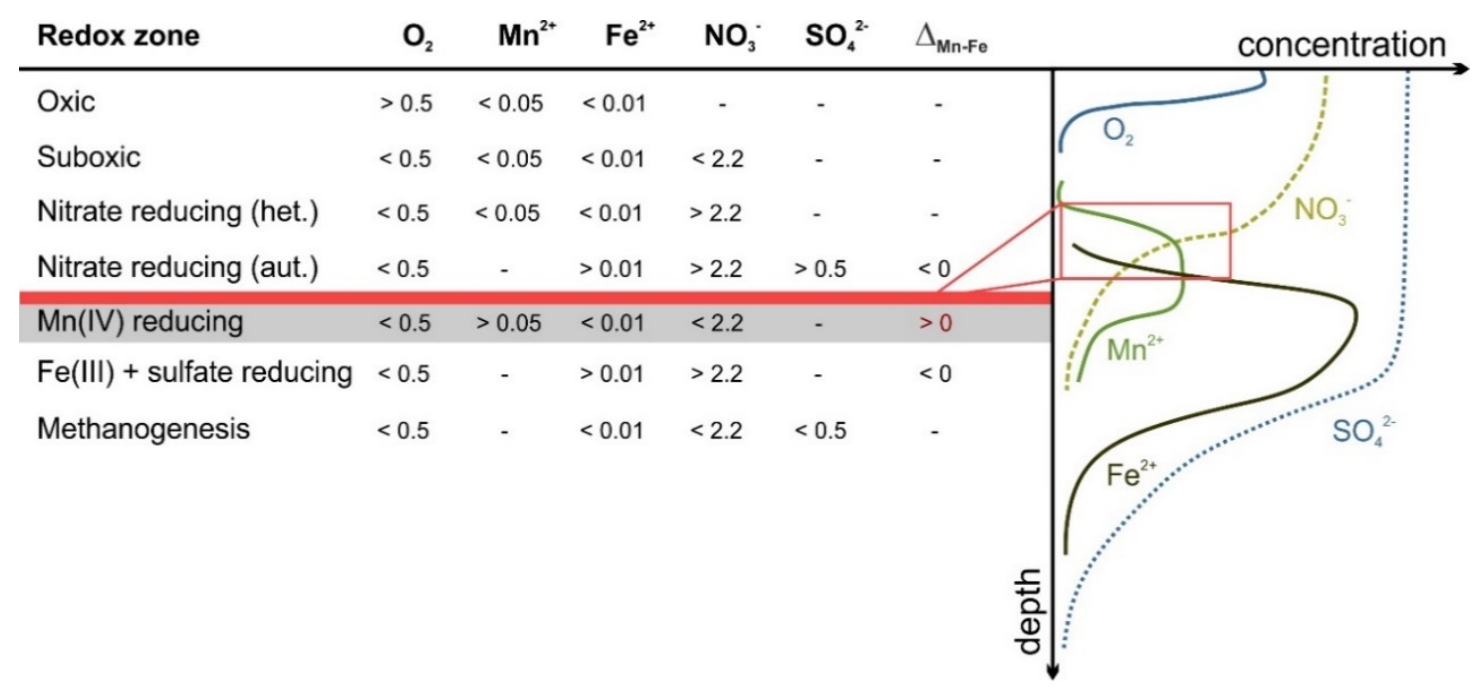

Figure 4. Typical concentration ranges $[\mathrm{mg} / \mathrm{L}]$ of redox indicator parameters (Christensen et al., 2000 and adapted after Jurgens et al., 2009).

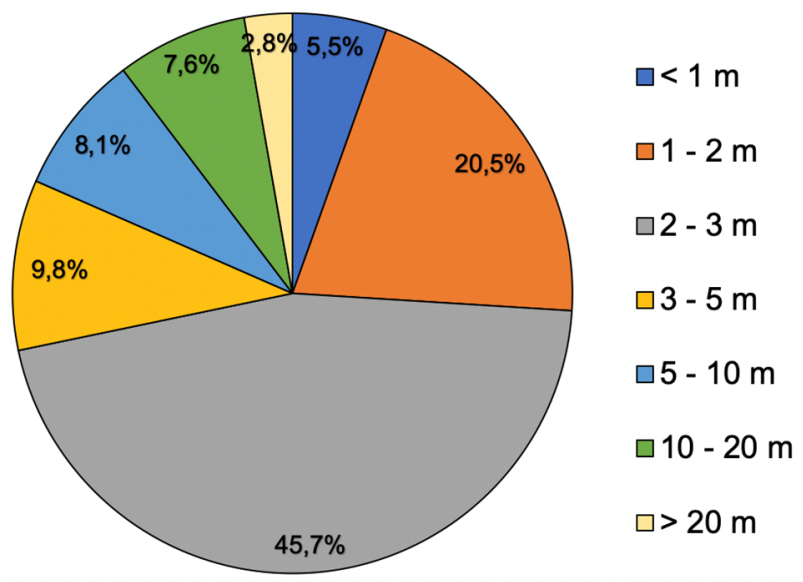

Figure 5. Percentage distribution of length of the monitoring screens in Lower Saxony in classes. 

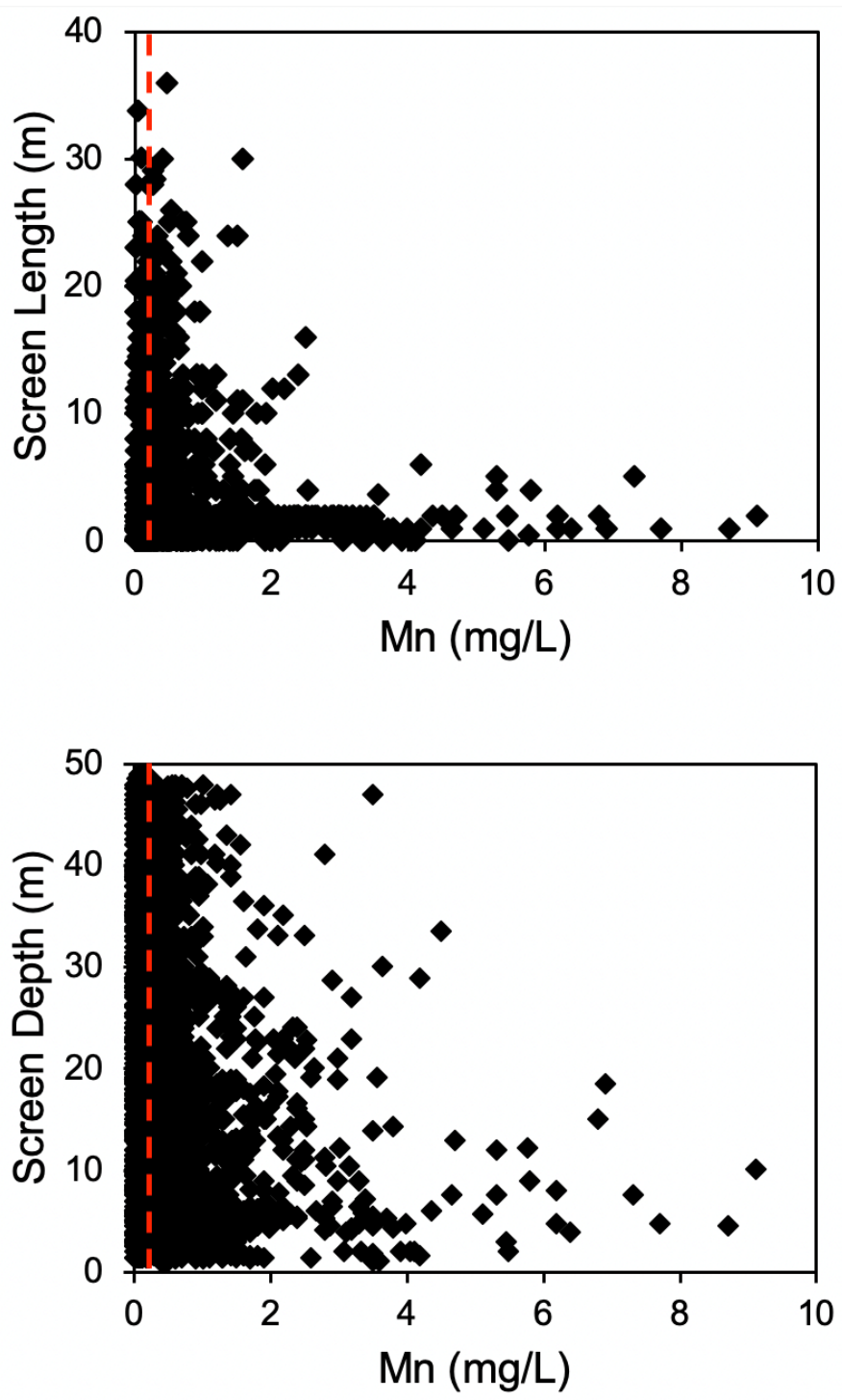

Figure 6. Variation of Mn concentrations in the three major hydrogeological units relative to screen length (top) and depth of screen (bottom). The depth is to the middle of the screen. Dashed red line indicates the $0.3 \mathrm{mg} / \mathrm{L} \mathrm{Mn}$ concentration.

In another study [40] conducted in the in the same area to assess nitrate in surficial groundwater, the authors tried to address the problem of overlapping redox zones in monitoring wells by grouping the wells in classes according to the depth of the screens below the groundwater table. Regardless, they found only limited spatial correlation even amongst monitoring wells in close proximity. Reason is that redox heterogeneity on ranges shorter than distances between monitoring wells impede such correlation. McMahon and Chapelle [41] and DeSimone et al. [42], who investigated principal aquifers in the US, described that, in addition to aquifer heterogeneity and flow-path complexity due to that geological complexity, long screens often led to mixed redox environments in single samples. Especially if electron acceptors such as pyrite or buried organic matter were abundant, this resulted in steep redox gradients causing different groundwater composition over short vertical and horizontal distances.

Monitoring wells with a $\Delta_{\mathrm{Mn}-\mathrm{Fe}}>0$ together with high nitrate concentrations are most likely drawing groundwater simultaneously from the nitrate, Mn-, and Fe reduction zones (Figure 4). This was remarkable because usually the Mn reduction zone is relatively narrow. Responsible for that observation was a high nitrate concentration that permeated into the Mn reduction zone and therefore, the conditions remained oxidizing enough for Fe mineral to remain stable. This effect of nitrate 
oxidizing Fe in the presence of Mn was described by Luther et al. [43] in marine sediments and by Kölle et al. [44] in groundwater. Koopmann et al. [11] simulated such a synchronistic appearance of redox environments in the laboratory and could show that Mn would remain stable in the presence of increasing nitrate concentrations as long as the amount of nitrate surplus was sufficient to oxidize Fe (Equation (3)).

$$
\mathrm{NO}_{3^{-}}+5 \mathrm{Fe}^{2+}+7 \mathrm{H}_{2} \mathrm{O} \rightarrow 0.5 \mathrm{~N}_{2}+5 \mathrm{FeOOH}+9 \mathrm{H}^{+}
$$

In this study, that process was identified in groundwater samples by a $\Delta_{\mathrm{Mn}-\mathrm{Fe}}>0$ and was corroborated by the Spearman's rank correlation analysis which showed a better correlation of Mn with $\Delta_{\mathrm{Mn}-\mathrm{Fe}} \geq 0$ in Geesten and lowlands than with Fe (Table 2).

Consequently, the $\Delta_{\mathrm{Mn}-\mathrm{Fe}}$ is a helpful indicator in groundwater monitoring programs in addition to the plain Mn concentration itself. $\Delta_{\mathrm{Mn} \text {-Fe }}$ shows not only a common Mn-reduction; the new parameter reveals overlapping redox zones indicating an influence of nitrate-surplus. In addition, $\Delta_{\mathrm{Mn}-\mathrm{Fe}}$ could prove to be a potential tool to identify monitoring wells, which target a certain redox environment, as demonstrated in Figure 7. Only those monitoring wells with screens less than $2 \mathrm{~m}$ in length show $\Delta_{\mathrm{Mn}-\mathrm{Fe}}$ "anomalies", i.e., $\Delta_{\mathrm{Mn}-\mathrm{Fe}}>0$. At the same time that group of wells has a large range of negative $\Delta_{\mathrm{Mn}-\mathrm{Fe}}$ values indicating that they also target particular redox zones which are characterized by an excess of Fe relative to Mn.

\subsection{Background Concentrations in Groundwater}

Additional to threshold values background concentrations are often applied as a criterion to assess groundwater quality [15]. The purpose of such background values is to describe the typical or "normal" composition of groundwater that is rarely affected by anthropogenic activities [18]. In this study background values for Mn were determined for the hydrogeological subunits that comprise the three major hydrogeological units: Geesten, tidal flats and fluviatile lowlands. Although considered individual subunits, the aquifer matrix of each of them is comparatively similar [14] and consequently, the background values differed only slightly within their respective hydrogeological subunits (Figure 3), while the differences between the major hydrogeological units were comparatively larger (Figure 3).

In addition to the aquifer matrix of a hydrogeological subunit other factors influence the background concentrations of a given element, such as, the groundwater recharge rate [45], land use [46], redox conditions [38], depth of the groundwater surface [40], geological heterogeneity [45] and screen length $[41,46]$. Of those factors, particularly the screen length and screen depth are complicating factors since they directly affect which redox zone is sampled and the degree of mixing between different redox zones. This bias of Mn concentration towards screen depth and screen length complicates or even prevents the determination of background values in the classical sense (see above). Thus, it would be necessary to determine background values for a multitude of redox conditions using monitoring wells with short screens to prevent mixing of groundwater from different redox zones.

To cope with mixed redox environments in wells is a known problem, e.g., [37], and thus, a robust classification scheme would allow to compare the composition of groundwater among monitoring wells with similar redox conditions. As mentioned above, the $\Delta_{\mathrm{Mn}-\mathrm{Fe}}$ can serve as an indicator showing mixed redox environments. In the study area those monitoring wells with a $\Delta_{\mathrm{Mn} \text {-Fe }}$ close to 0 also were those wells where the $50 \mathrm{mg} / \mathrm{L}$ threshold concentration for nitrate was most often exceeded (Figure 7B). At the same time those wells also had Mn concentrations that were higher than the background concentrations calculated for their respective subunits. This phenomenon could also be observed by plotting the data geographically (Figure 8). The locations where $\Delta_{\mathrm{Mn}-\mathrm{Fe}}>0$ are more or less confined to those areas where nitrate is above $50 \mathrm{mg} / \mathrm{L}$ (Figure 9). The high nitrate concentrations are thought to be caused by intensive agriculture [40] and thus, Mn concentrations exceeding the background values and a $\Delta_{\mathrm{Mn}-\mathrm{Fe}}$ close to or above 0 suggests that diffuse input of nitrate resulted in a wide spread change of redox conditions in the surficial part of the aquifers. 

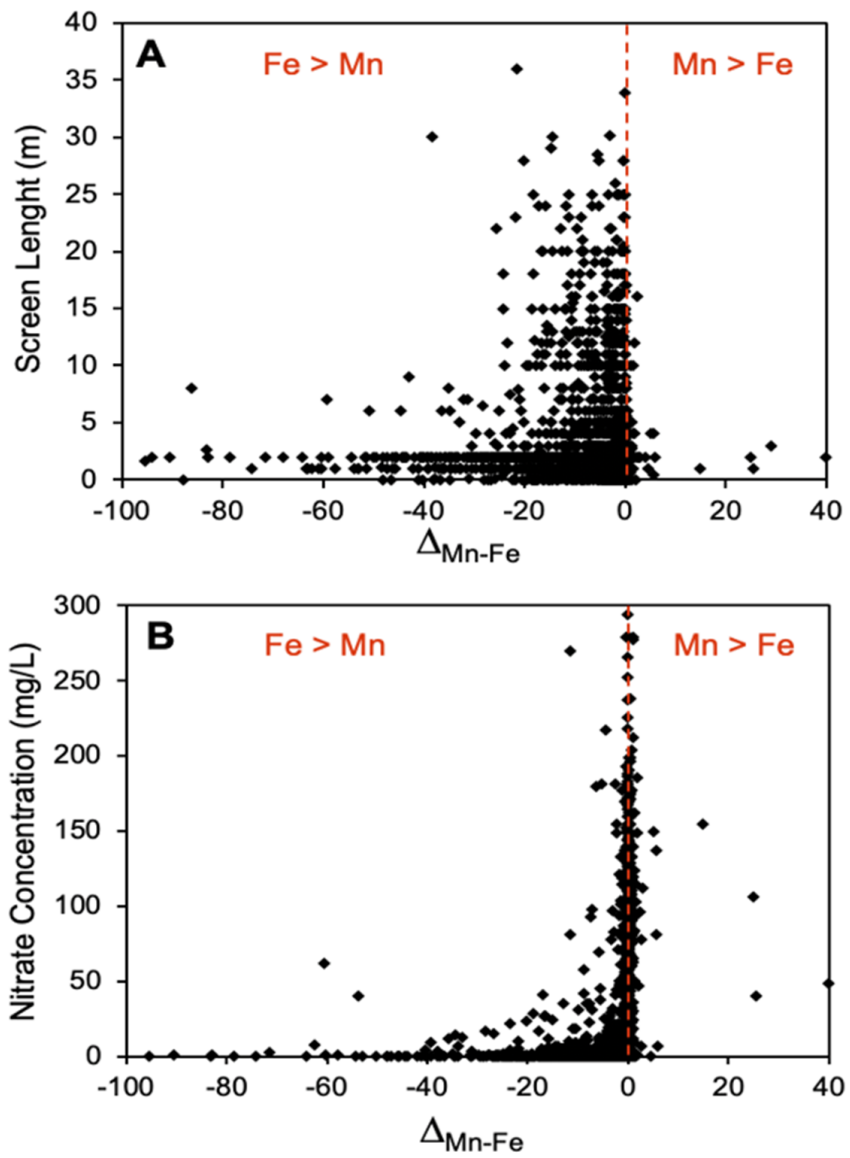

Figure 7. Relationship between monitoring well screen length (A), nitrate concentration (B) and $\Delta_{\mathrm{Mn}-\mathrm{Fe}}$. Large variations are only seen in wells with shorter screens.

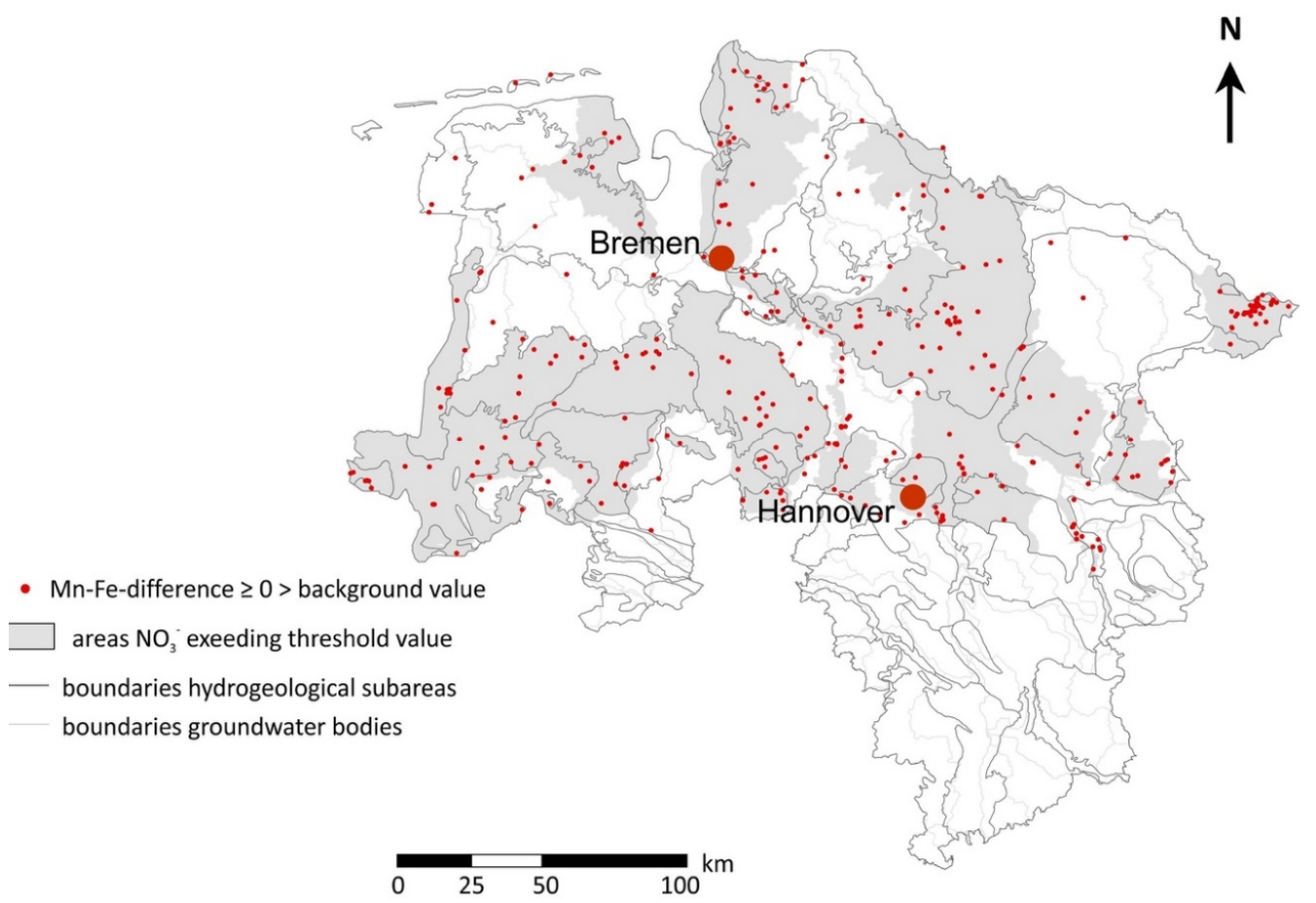

Figure 8. Areas with nitrate concentrations above the drinking water standard of $50 \mathrm{mg} / \mathrm{L}$ and monitoring wells with a $\Delta_{\mathrm{Mn}-\mathrm{Fe}} \geq 0$ and exceeding the local background value of $\mathrm{Mn}$ (209 piezometers;). 
In the groundwater in the poorly buffered aquifers in the study area, nitrate could also result from the oxidation of ammonium $\left(\mathrm{NH}_{4}{ }^{+}\right)$according to the following reaction [47],

$$
\mathrm{NH}_{4^{+}}+2 \mathrm{O}_{2} \rightarrow \mathrm{NO}_{3^{-}}+2 \mathrm{H}^{+}+\mathrm{H}_{2} \mathrm{O}
$$

Causing elevated nitrate and a low $\mathrm{pH}$. McMahon et al. [1] considered the same reaction to be a control of Mn occurrence in groundwater in the northeastern U.S. where glacial sediments are prevalent, similar to the sediments in northern Germany. They found that $\mathrm{pH} 6$ seemingly divided their data, where samples with a $\mathrm{pH}>6$ had low nitrate and oxygen and those with a $\mathrm{pH}<6$ had significantly higher nitrate and oxygen concentrations and concluded that at a $\mathrm{pH}>6$ anoxic $\mathrm{Mn}$ reduction takes place, whereas at a $\mathrm{pH}<6$ nitrate and oxygen concentrations were still high enough to inhibit microbial Mn reduction. In the groundwater dataset from northern Germany approximately $35 \%$ of the samples had a $\mathrm{pH}<6$ and in comparing Mn concentrations to $\mathrm{pH}$ and nitrate the division caused by $\mathrm{pH} 6$ could be nicely demonstrated. Looking at the data without a consideration of nitrate concentrations, elevated $\mathrm{Mn}$ concentrations were almost evenly distributed across the $\mathrm{pH}$ range from 4 to 8 (Figure 9A). However, once samples with nitrate concentrations less than $50 \mathrm{mg} / \mathrm{L}$ were excluded, the dominance of elevated Mn concentrations clearly shifted into the range from 4 to 6 (Figure 9B).

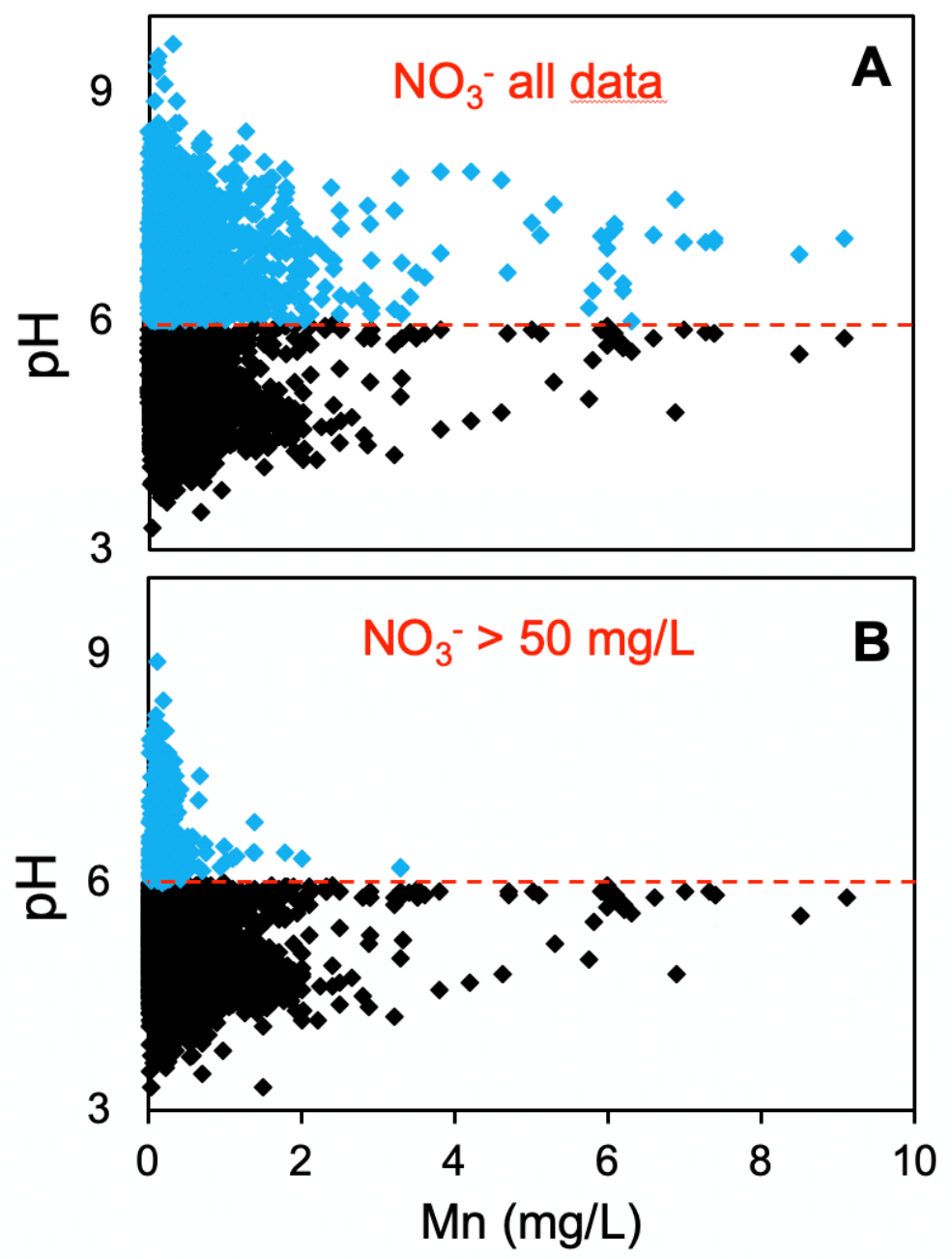

Figure 9. $\mathrm{Mn}-\mathrm{pH}$ relationship at varying nitrate $\left(\mathrm{NO}_{3}{ }^{-}\right)$concentrations, i.e., (A) all concentrations and (B) concentrations above the drinking water threshold of $50 \mathrm{mg} / \mathrm{L}$. The horizontal dashed red line marks pH 6 and the vertical dashed red line indicates the $0.3 \mathrm{mg} / \mathrm{L}$ "non-enforced" U.S. Health Reference Level for Mn. 
The nitrate concentration affected Mn and Fe Equation (3) and consequently the $\Delta_{\mathrm{Mn} \text {-Fe, }}$ but could have influenced further redox sensitive parameter as well [45]. This was similarly described for heavy metals such as cadmium [15] and uranium [48] or metalloids [35] like arsenic.

Given the susceptibility of Mn concentrations in groundwater to the above discussed factors, such as well depth, screen length, and nitrate or ammonium input, it becomes clear that Mn background concentrations have to be treated carefully. They cannot be used as an indicator of groundwater condition with respect to anthropogenic activities. Accordingly, background values for $\mathrm{Mn}$ and other parameters linked to redox environments represent more a recent baseline than a background "corresponding to no, or only very minor, anthropogenic alterations" [18]. This is of vital importance because such background values might be applied instead of threshold values to assess the state of groundwater.

\subsection{Trends of Mn Concentration}

The surficial groundwater in the study area is known for elevated nitrate concentrations caused by intensive use of fertilizers on arable land $[15,49]$ and numerous authors described that a long lasting input of nitrate towards groundwater influenced the respective redox environment, e.g., [4,45]. Considering that Koopmann et al. [11] demonstrated the close relationship between nitrate and Mn, one would expect that nitrate and Mn should behave similarly in our study area.

To further explore this, trend tests for $\mathrm{Mn}$ and Fe were conducted for 224 monitoring wells in the Weser-Ems region of our study area. This region is characterized by continued intensive agricultural use [50] so that trends in groundwater composition due to nitrate input from fertilizer were hypothesized. However, only about $20 \%$ of the tested monitoring wells showed increasing Mn concentrations trends, while $25 \%$ had decreasing Mn concentrations. More than half of the monitoring wells had no trends or were stable. Approximately the same applied to Fe trends (Table 3). This seemed to be in disaccord with the expectation of increasing Mn trends caused by a permanent nitrate surplus at the surface due to intensive agriculture. The constant input of nitrate should propagate the nitrate reduction front, which in turn should move the Mn reduction front and thus cause the constant release of Mn, leading to either increasing trends or stable conditions. Nevertheless, the observation of opposing trends did neither state nor proof the hypothesis wrong. In fact, this raises the question to what extend changes could have been expected. Recently, Houben et al. [51] computed the movement of redox processes in the Weser-Emsland and concluded that on average the autotrophic nitrate reduction front moved less than a cm per year, which was slower than the vertical groundwater flow of $1 \mathrm{~m} / \mathrm{yr}$. The slow movement of the nitrate reduction front was credited to the denitrification capacity in the aquifer. Within a ten-year timespan, this would lead to a propagation of $10 \mathrm{~cm}$. Hypothetically, even within a short screen length of $1 \mathrm{~m}$, the groundwater sampled could not have been influenced dramatically over the course of a 10 years period. In screens longer than a meter the potentially observed change in groundwater composition would be even less and thus be beyond the accuracy of available observation data.

In the end it was not surprising that in the study area those monitoring wells displaying Mn concentrations trends were not as common as expected. Prospectively, the next trend tests or trend analyses should focus on the hydrogeological data of well-characterized single wells with short screens. Particularly, the travel time from infiltration to arrival in the screens, land use history in the catchment of the monitoring well and capacities for oxidation and reduction in the aquifer should be known or estimated. Only based on the analyses of properly characterized wells an investigation on spatial extend of trends would be a separate and follow-up step.

\section{Conclusions}

This and numerous other studies have demonstrated that redox processes are a major influence controlling the chemical composition of groundwater. This complicates groundwater monitoring, since redox processes vary on scales of centimeters to meters, while well screens are often larger than $2 \mathrm{~m}$ 
and horizontally, the wells in a monitoring net are kilometers apart. This becomes problematic if it is necessary to display a concise picture describing the composition of surficial groundwater in order to identify problematic areas and to design appropriate measures for groundwater protection.

In cases where new groundwater monitoring nets will be established, short screens in monitoring wells would allow to sample groundwater with marginal mixing of redox environments. In existing, long lasting measuring programs with longer screens in the monitoring wells like in our study area, it should be a helpful step to characterize every monitoring well according to the redox environments that are sampled in the respective screens.

In addition this study recommends to apply the parameter $\Delta_{\mathrm{Mn}-\mathrm{Fe}}$ because this parameter displays a very crucial redox environment in surficial groundwater. It becomes positive in a Mn reducing environment, especially when nitrate is present in the Mn reducing zone and depletes Fe due to oxidation. This situation often appears in areas where nitrate reaches groundwater due to intensive fertilizer and manure use on arable land. Consequently, this parameter reveals two advantages. Firstly, it identifies monitoring wells with screens in a redox environment of interest and second can be applied retroactive to long lasting data sets because $\mathrm{Mn}$ and Fe have been part of routine monitoring programs for quite some time. Additionally, the parameter $\Delta_{\mathrm{Mn}-\mathrm{Fe}}$ is a candidate in order to see a potential change of the redoxcline due to nitrate input to surficial groundwater. In the end, the identification of such areas and the control of the effectiveness of measures to protect groundwater from intensive fertilizer application are two important purposes of recent surveillance monitoring programs.

In this study, $\Delta_{\mathrm{Mn}-\mathrm{Fe}}$ together with nitrate concentrations exceeding $50 \mathrm{mg} / \mathrm{L}$ were used to identify fertilizer-borne input of nitrate. However, the main factor controlling Mn occurrence was seemingly the depth of monitoring wells and the screen-length. Elevated concentrations of $\mathrm{Mn}$ and a high $\Delta_{\mathrm{Mn}-\mathrm{Fe}}$ were generally found in shallow wells and wells with short screen-lengths.

Author Contributions: Conceptualization K.H. and T.P.; Methodology K.H., I.G., and T.P.; Investigation I.G., Resources T.P.; Writing—original draft preparation I.G. und K.H.; Writing—review and editing T.P.; Supervision K.H.; Project administration and funding acquisition T.P. All authors have read and agreed to the published version of the manuscript.

Funding: This work was partly funded by the State of Lower Saxony Division of Groundwater, Forschungsprojekt 62170-11-02/CD A31.

Acknowledgments: Authorities in Lower Saxony and Bremen, here the Senator for environment (SUBV), provided access to the data for this project. This study was supported by Niedersächsischer Landesbetrieb für Wasserwirtschaft, Küsten und Naturschutz (NLWKN). We appreciated fruitful discussions with and help from D. Budziak and J. Elbracht from the Geological Survey of Lower Saxony (LBEG), D. de Vries (NLWKN) and A. Kubier (MKP Müller-Kirchenbauer Ingenieurgesellschaft $\mathrm{mbH}$ ). The comments by two anonymous reviewers helped to improve this contribution.

Conflicts of Interest: The authors declare no conflict of interest.

\section{References}

1. McMahon, P.B.; Belitz, K.; Reddy, J.E.; Johnson, D. Elevated manganese concentrations in united states groundwater, role of land surface-soil-aquifer connections. Environ. Sci Technol. 2019, 53, 29-38. [CrossRef] [PubMed]

2. Appelo, C.A.J.; Postma, D. Geochemistry, Groundwater and Pollution; Balkema Publishers: Leiden, The Netherlands, 2005; p. 649.

3. Bjerg, P.L.; Ruegge, K.; Pedersen, J.K.; Christensen, T.H. Distribution of redox-sensitive groundwater quality parameters downgradient of a landfill (grindsted, denmark). Environ. Sci. Technol. 1995, 29, 1387-1394. [CrossRef] [PubMed]

4. Christensen, T.H.; Bjerg, P.L.; Banwart, S.A.; Jakobsen, R.; Heron, G.; Albrechtsen, H.J. Characterization of redox conditions in groundwater contaminant plumes. J. Contam. Hydrol. 2000, 45, 165-241. [CrossRef]

5. Stumm, W. Chemische prozesse bei der bildung anoxischer grundwasser. Schweiz. Ing. und Archit. 1988, $106,119-128$. 
6. Coetzee, D.J.; McGovern, P.M.; Rao, R.; Harnack, L.J.; Georgieff, M.K.; Stepanov, I. Measuring the impact of manganese exposure on children's neurodevelopment: Advances and research gaps in biomarker-based approaches. Environ. Health 2016, 15, 91. [CrossRef] [PubMed]

7. Marins, K.; Lazzarotto, L.M.V.; Boschetti, G.; Bertoncello, K.T.; Sachett, A.; Schindler, M.S.Z.; Chitolina, R.; Regginato, A.; Zanatta, A.P.; Siebel, A.M.; et al. Iron and manganese present in underground water promote biochemical, genotoxic, and behavioral alterations in zebrafish (danio rerio). Environ. Sci. Pollut. Res. Int. 2019, 26, 23555-23570. [CrossRef] [PubMed]

8. Wasserman, G.A.; Liu, X.; Parvez, F.; Ahsan, H.; Levy, D.; Factor-Litvak, P.; Kline, J.; Van Geen, A.; Slavkovich, V.; LoIacono, N.J.; et al. Water manganese exposure and children's intellectual function in araihazar, bangladesh. Environ. Health Perspect 2006, 114, 124-129. [CrossRef]

9. Wedepohl, K.H. The composition of the continental crust. Geochim. et Cosmochim. Acta 1995, 59, 1217-1232. [CrossRef]

10. Wendland, F.; Blum, A.; Coetsiers, M.; Gorova, R.; Griffioen, J.; Grima, J.; Hinsby, K.; Kunkel, R.; Marandi, A.; Melo, T. European aquifer typology: A practical framework for an overview of major groundwater composition at european scale. Env. Geol. 2008, 55, 77-85. [CrossRef]

11. Koopmann, S.; Fröllje, H.; Hamer, K.; Kubier, A.; Pichler, T. Eisen-mangan-anomalien im grundwasser-Analyse der beeinflussenden prozesse (fe-mn-anomalies of groundwater-Analysis of influencing processes). Grundwasser 2020, 25, 113-126. [CrossRef]

12. Jones, E.; Nico, P.; Ying, S.; Regier, T.; Thieme, J.; Keiluweit, M. Mn-driven carbon oxidation at oxic-anoxic interfaces. Environ. Sci. Technol. 2018, 52, 12349-12357. [CrossRef] [PubMed]

13. Droll, M. Isenbeck-Schröter, M. Charakterisierung der hydrochemischen verhältnisse im oberflächennahen grundwasserleiter im block- und hollerland (bremen). In Geowissenschaften und Umwelt; Matschullat, J., Müller, G., Eds.; Springer: Berlin/Heidelberg, Germany, 1994; pp. 115-120.

14. Elbracht, J.; Meyer, R.; Reutter, E. Hydrogeological areas and subareas in lower saxony. GeoBericht 2016, 3 , 3-118.

15. Kubier, A.; Hamer, K.; Pichler, T. Cadmium background levels in groundwater in an area dominated by agriculture. Integr. Environ. Assess. Manag. 2020, 16, 103-113. [CrossRef] [PubMed]

16. BKG Bundesamt für Kartographie und Geodäsie. Corine Land Cover $10 \mathrm{Ha}$ Clc10 (2012) Lbm-de2012-Land Cover Model Germany, Reference Year 2012; BKG Bundesamt für Kartographie und Geodäsie: Leipzig, Germany, 2018.

17. European Commission. Directive 2000/60/ec of the European Parliament and of the Council of 23 October 2000 Establishing a Framework for Community Action in the Field of Water Policy; 2000/60/EC.; European Commission: Brussels, Belgium, 2000; p. 72.

18. European Commission. Directive 2006/118/ec of the European Parliament and of the Council of 12 December 2006 on the Protection of Groundwater Against Pollution and Deterioration; 2006/118/EC.; Official Journal of the European Communities: Brussels, Belgium, 2006; p. 13.

19. Shand, P.; Edmunds, W.M. The baseline inorganic chemistry of european groundwaters. In Natural Groundwater Quality; Edmunds, W.M., Malden, P.S., Eds.; Blackwell Publishing: Oxford, UK, 2008; pp. $22-58$.

20. BGR, Bundesanstalt für Geowissenschaften und Rohstoffe. Hydrogeologische Karte Von Deutschland 1:200.000, Hintergrundwerte (Hük200 Hgw); Bundesanstalt für Geowissenschaften und Rohstoffe BGR: Hannover, Germany, 2014.

21. ESRI Environmental Systems Research Institute. Arcgis Desktop 10; ESRI Environmental Systems Research Institute: Redlands, CA, USA, 2018.

22. Belkhiri, L.; Boudoukha, A.; Mouni, L. A multivariate statistical analysis of groundwater chemistry data. International journal of environmental research. Int. J. Environ. Res. 2011, 5, 537-544.

23. Zghibi, A.; Merzougui, A.; Zouhri, L.; Tarhouni, J. Understanding groundwater chemistry using multivariate statistics techniques to the study of contamination in the korba unconfined aquifer system of cap-bon (north-east of tunisia). J. Afr. Earth Sci. 2014, 89, 1-15. [CrossRef]

24. Güler, C.; Thyne, G.D.; McCray, J.E.; Turner, A.K. Evaluation of graphical and multivariate statistical methods for classification of water chemistry data. Hydrogeol. J. 2002, 10, 455-474. [CrossRef]

25. Leyer, I.; Wesche, K. Multivariate Statistik in Der Ökologie. EINE Einführung; Springer: Berlin/Heidelberg, Germany, 2007. 
26. Lepeltier, C. A simplified statistical treatment of geochemical data by graphical representation. Econ. Geol. 1969, 64, 538-550. [CrossRef]

27. Wagner, B.; Walter, T.; Himmelsbach, T.; Clos, P.; Beer, A.; Budziak, D.; Dreher, T.; Fritsche, H.; Hübschmann, M.; Marcinek, S.; et al. Hydrogeochemische hintergrundwerte der grundwässer deutschlands als web map service. Grundwasser 2011, 16, 155-162. [CrossRef]

28. Miah, M.R.; Ijomone, O.M.; Okoh, C.O.A.; Ijomone, O.K.; Akingbade, G.T.; Ke, T.; Krum, B.; Da Cunha Martins, A., Jr.; Akinyemi, A.; Aranoff, N.; et al. The effects of manganese overexposure on brain health. Neurochem. Int. 2020, 135, 104688. [CrossRef]

29. Kullar, S.S.; Shao, K.; Surette, C.; Foucher, D.; Mergler, D.; Cormier, P.; Bellinger, D.C.; Barbeau, B.; Sauve, S.; Bouchard, M.F. A benchmark concentration analysis for manganese in drinking water and iq deficits in children. Environ. Int. 2019, 130, 104889. [CrossRef]

30. Tobiason, J.E.; Bazilio, A.; Goodwill, J.; Mai, X.; Nguyen, C. Manganese removal from drinking water sources. Curr. Pollut. Rep. 2016, 2, 168-177. [CrossRef]

31. Pichler, T.; Renshaw, C.E.; Sültenfuß, J. Geogenic as and mo groundwater contamination caused by an abundance of domestic supply wells. Appl. Geochem. 2017, 77, 68-79. [CrossRef]

32. Pichler, T.; Koopmann, S. Should monitoring of molybdenum (mo) in groundwater, drinking water and well permitting made mandatory? Environ. Sci. Technol. 2020, 54, 1-2. [CrossRef] [PubMed]

33. Deepali, K.K.G. Metals concentration in textile and tannery effluents, associated soils and ground water. $N$. Y. Sci. J. 2010, 3, 82-89.

34. Caruso, B.S.; Mirtskhulava, M.; Wireman, M.; Schroeder, W.; Kornilovich, B.; Griffin, S. Effects of manganese mining on water quality in the caucasus mountains, republic of georgia. Mine Water Environ. 2012, 31, 16-28. [CrossRef]

35. Ying, S.; Schaefer, M.; Cock-Esteb, A.; Li, J.; Fendorf, S. Depth stratification leads to distinct zones of mn and arsenic contaminated groundwater. Environ. Sci. Technol. 2017, 51, 8926-8932. [CrossRef]

36. Froelich, P.N.; Klinkhammer, G.P.; Bender, M.L.; Luedtke, N.A.; Heath, G.R.; Cullen, D.; Dauphin, P.; Hammond, D.; Hartmann, B.; Maynard, V. Early oxidation of organic matter in pelagic sediments of the eastern equatorial atlantic: Suboxic diagenesis. Geochim. et Cosmochim. Acta 1979, 43, 1075-1790. [CrossRef]

37. Jurgens, B.C.; McMahon, P.B.; Chapelle, F.H.; Eberts, S.M. An excel ${ }^{\circledR}$ workbook for identifying redox processes in ground water. U.S. Geol. Surv. Open File Rep. 2009, 8. Available online: http://pubs.usgs.gov/of/2009/1004 (accessed on 30 July 2020).

38. Wriedt, G.; Randt, C. Phosphat im grundwasser niedersachsens-Verteilung, einflussfaktoren und schwellenwert. Grundwasser 2019, 24, 109-127. [CrossRef]

39. Gillispie, E.C.; Austin, R.E.; Rivera, N.A.; Bolich, R.; Duckworth, O.W.; Bradley, P.; Amoozegar, A.; Hesterberg, D.; Polizzotto, M.L. Soil weathering as an engine for manganese contamination of well water. Environ. Sci. Technol. 2016, 50, 9963-9971. [CrossRef]

40. Wriedt, G.; De Vries, D.; Eden, T.; Federolf, C. Regionalisierte darstellung der nitratbelastung im grundwasser niedersachsens. Grundwasser 2019, 24, 1-15. [CrossRef]

41. McMahon, P.B.; Chapelle, F.H. Redox processes and water quality of selected principal aquifer systems. Groundwater 2008, 46, 59-71. [CrossRef] [PubMed]

42. DeSimone, L.; McMahon, P.B.; Rosen, M.R. The quality of our nation's waters-Water quality in principal aquifers of the united states, 1991-2010. U.S. Geol. Surv. Circ. 2014, 1930, 151.

43. Luther, G.W.; Sundby, B.; Lewis, B.L.; Brendel, P.J.; Silverberg, N. Interactions of mn with the nitrogen cycle: Alternative pathways to dinitrogen. Geochim. et Cosmochim. Acta 1997, 61, 4043-4052. [CrossRef]

44. Kölle, W.; Strebel, O.; Böttcher, J. Formation of sulfate by microbial denitrification in a reducing aquifer. Form. Sulfate Microb. Denitrification Reducing Aquifer 1985, 3, 35-40.

45. Tesoriero, A.; Terziotti, S.; Abrams, D.B. Predicting redox conditions in groundwater at a regional scale. Environ. Sci. Technol. 2015, 49, 9657-9664. [CrossRef]

46. Knoll, L.; Breuer, L.; Bach, M. Large scale prediction of groundwater nitrate concentrations from spatial data using machine learning. Sci. Total. Environ. 2019, 668, 1317-1327. [CrossRef]

47. Böhlke, J.K. Groundwater recharge and agricultural contamination. Hydrogeol. J. 2002, 10, 153-179. [CrossRef]

48. Riedel, T.; Kübeck, C. Uranium in groundwater-A synopsis based on a large hydrogeochemical data set. Water Res. 2018, 129, 29-38. 
49. Kubier, A.; Pichler, T. Cadmium in groundwater-A synopsis based on a large hydrogeochemical data set. Sci. Total. Environ. 2019, 831-842. [CrossRef]

50. Houben, G.J.; Martiny, A.; Baßler, N.; Langguth, H.-R.; Plüger, W.L. Assessing the reactive transport of inorganic pollutants in groundwater of the bourtanger moor area (nw germany). Environ. Geol. 2001, 41, 480-488.

51. Houben, G.H.; Sitnikova, M.A.; Post, V.E.A. Terrestrial sedimentary pyrites as a potential source of trace metal release to groundwater e a case study from the emsland, germany. Appl. Geochem. 2017, 76, 99-111. [CrossRef]

(C) 2020 by the authors. Licensee MDPI, Basel, Switzerland. This article is an open access article distributed under the terms and conditions of the Creative Commons Attribution (CC BY) license (http://creativecommons.org/licenses/by/4.0/). 